\title{
Computer And Religiosity In Turbulency Economy With Covid
}

\author{
RM Aziz \\ \{h.shiradynivi@gmail.com\}
}

State Islamic University Jakarta

\begin{abstract}
When Islamic civilization took over the world, precisely in the Caliphate era, Muslim engineers had mastered computer technology. The technology was developed by Muslim scientists at that time was not a digital computer, but an analog computer. The Hahslm H = Ah (SLM) equation can be obtained with one single theory which is also based on Islamic values and comes from the Qur'an the word of God. This God equation will be the answer to conventional scientific development based on empirical values along with Islamic science based on worship values or intangible values. The problem in this research is how the relationship between the theory of law with computer techniques in Islam. The purpose of this study is to obtain empirical evidence relating to the relationship between the theory of law and computer techniques in Islam. The data analysis method used in this study is a qualitative data analysis method. The results showed that the relationship between the theory of law and Islamic computer engineering was the theory of law being a moderate variable on computer techniques that differed in influencing the progress of Muslims. Some of the expected contributions from this study are (1) as insight material for researchers about the relationship of the theory of law to Computer Engineering in Islam. and (2) The results of this study are expected to contribute to the development of theory, especially those related to computer engineering in Islam. And the Role of Information Technology in the Economy in the country's economy, and its influence on COVID-19.
\end{abstract}

Keywords: computer, technology, economic, religiosity, COVID-19

\section{Introduction}

Artificial Intelligence consists of two words: Intelligence and Artificial. Intelligence means things related to intelligence, ingenuity, and wisdom. While Artificial (artificial) means imitation, something is not natural or artificial. "Science and techniques that are based on computer methods to program an application and intelligent machine by imitating the intelligence of humans or sunnatullah who maintain and regulate all nature and its contents exist on land, sea, and air. Computer science experts try to innovate by creating machines that can see, hear, talk, think, count, walk, run, search, and all human abilities, except to have emotions, intuition, be creative, and others that are so subjective.

In Islam, the development of science itself progressed and developed rapidly during the Abbasid Dynasty. Muslim engineers had already mastered computer technology. A series of tools using analog computer principles have been discovered by Islamic scientists. The tools are generally used for various scientific activities. In its golden age, Muslim astronomers 
managed to find various types of the astrolabe. Technological developments have positive and negative impacts on human life, and the development of these technologies is closely related to society. Technology has a role in the Covid-19 outbreak. From here the Government will make an application based on information technology-based systems about the development of the corona or Covid-19 case. According to Roikhan (2015) computer can be related to Hahslm Theory. Theory $\mathrm{H}$ is interpreted as the three dominant archetype theory with certain contexts in five dimensions of invariant arrangement. Viewed from several aspects. The term computer has a broad and different meaning for each person. The term computer (computer) is taken from the Latin computer which means to count (to compute or to reckon).

Computer is an electronic device that is capable of performing several tasks, Blissmer (1985). Sanders (1985) A computer is an electronic system for manipulating data. There are three important terms, input (data), data processing, and information (output). These components are the same with Hahslm that consist of source, result, and reflexivity. Coronavirus infection called Covid-19 and was first discovered in the city of Wuhan, China, at the end of December 2019. The impact of Covid-19 on Islam and knowledge. The coronavirus not only claimed thousands of lives but also changed the ways of human life throughout the world starting from the interaction of others and the process of relating to God. Some people confine themselves at home, avoid crowded places, and postpone trips to other places. Others changed the procedure from shaking hands and hugging to greeting using elbows and legs. Coronavirus outbreaks also have an impact on the religious life of humanity. Several churches, mosques, temples, and synagogues have changed the way of worship to curb the spread of Covid-19 disease. The Grand Mosque in Mecca is usually filled with thousands of pilgrims, but that number is now drastically reduced. The Grand Mosque has been reopened after undergoing sterilization, but around the Ka'bah there are still no barriers installed so that people do not touch it. Prohibition of visiting Mecca and Medina is still in force. Various Muslims from all over the world usually come to undergo the Umrah that lasts throughout the year. And the number of mosques that were temporarily closed to prevent the spread of co-19 so that Muslims could not perform the prayers in the mosque, not to mention during the fasting month the Muslims could not perform the prayers of the oldest prayers in the mosque. Muslim works with computer to avoid Covid-19. Although economy shrinks because of the decreasing of activity but those help human to save life.

There is no medical expert who knows how many victims will fall due to being infected with the Coronavirus. Likewise, no economist can predict firmly how bad economic conditions will be during the critical times of the Covid-19 outbreak. However, certainly, the spread of the disease that originated in China not only threatens human lives but also disrupts various economic and business activities. No exception, Islamic economic and business activities. According to data from the Central Statistics Agency, last year the value of Indonesia's non-oil and gas exports to China reached 25.7 billion US dollars. This value is far greater than the value of Indonesia's non-oil and gas exports to the United States and to Japan, which are ranked second and third respectively. Looking at the developments that have taken place in the last few days, with many cases of Covid-19 infections in Indonesia, it seems that the local impact of the spread of Covid-19 will be far greater.

\section{Methodology}

This research is based on secondary data, especially literature containing Sharia regulations and non-sharia approaches for computer users. This research is on desk-based and library-oriented research. To find out the relationship between economic theory, co-19, and 
law with computer techniques to advance Muslims, the authors consulted published literature, research monograms, journals, and magazines in the fields of technology, science, and Islam.

In this case, the secondary data comes from Islamic and conventional literature. It is worth mentioning here that the Qur'an and Hadith are used in this study as original and primary sources of data for their respective themes and concepts. From this research, we can see the interrelationship of the theory of hslm, technology, economics, Covid-19. This research focuses on the influence of computer engineering and its relationship with economics and Covid-19 as well as the hahlsm theory to advance the lives of Muslims in the world of effects, and social networking factors in presentation, and publicizing Islam. In this research, the main objective is to see how big is the role of computer engineering which plays a very important role in advancing Islam.

\section{Result and Discussion}

Translation analysis of three elements that form a Grand Design Kaffah (Roikhan: 2014. This paradigm instructs people to build all their thoughts based on Islamic worldview. The IMF projects that economic growth in developed countries this year will be minus 6.1 percent. While countries with high economic growth and developing countries will grow minus 1 percent by including China. If excluding China from this group, economic growth will be minus 2.2 percent. To prevent the rapid spread of Covid-19 in Indonesia, the government finally decided to implement the Large-Scale Social Restriction (PSBB) on March 31, 2020, almost a month since the Covid-19 case was first discovered in Indonesia.

The government economy was still said to be stable at 500,084, then as the pandemic was going on the government economy also experienced a decline due to adjusting the appropriate methods and policies to restore the economy to normal again. Then it can be concluded that the existence of Full Lockdown by the government in dealing with a pandemic will greatly affect the condition and stability of the country's economy. With this, the government should before Full Lockdown must regulate its Economic Development strategy so that it does not experience a decline and is always stable. To overcome the pandemic, government assistance is needed both physically and mentally so that the pandemic ends quickly and the economy continues to develop for the better.

\section{Conclusion}

Islam was an expert and inventor in various fields of science and technology during the caliphate but now advances in science and technology in the decades of the twentieth century have placed countries with Muslim-majority populations in marginal positions. The importance of Information Technology in Islam is duly recognized in the Muslim world. AlQur'an and Al-Hadith are the standard (miqyas) of science and technology and not the source of science and technology. That is, whatever the science and technology concept developed, it must be Computer Engineering, Theory of Hahslm as Moderation and The Progress of Life of Muslim. And related to COVID -19 at this time we now have to follow the existing government regulations by staying at home, working at home, worshiping at home, schooling at home, because until now corona victims are increasing and don't know when this virus will disappear. 


\section{References}

[1]. Al-Baghdadi, Abdurrahman. "Sistem Pendidikan di Masa Khilafah Islam". Bagil: Al-

[2]. Izzah, 1996.

[3]. Departemen Agama. "Al-Qur'an dan Terjemahnya”. Jakarta, 2003.

[4]. Aziz, Muhammad Roikhan. "Dida Dan Kada Dalam Bahasa, Agama, Serta Keragaman Budaya". Jurnal Dialektika Vol. 1 No. 1 Juni 2014.

[5]. Aziz, Muhammad Roikhan. "Teori H Sebagai Ilmu Wahyu Dan Turats Dalam Islam”. Jurnal Ushuluddin Vol. 24 No. 1, Januari - Juni 2016.

[6]. Farghal, Hasan. "Pokok Pikiran Tentang Hubungan Ilmu Dengan Agama". TTP, 1994.

[7]. Fatah, Rohadi Abdul. "Ilmu Dan Eknologi Dalam Islam”. Jakarta: PT Rineka Cipta. 1992.

[8]. Hamacher V.C, Et Al.”Computer Organization”. New York: Mcgraw-Hill. 2001.

[9]. Hosseini, Seyed Ebrahim., Ramchahi, Abdollatif Ahmadi., Yusuf, Raja Jamilah Raja Yusuf. "The Impact of Information Technology on Islamic Behaviour". Journal of Multidisciplinary Engineering Science and Technology (JMEST)". Vol. 1 Issue 5, December 2014.

[10]. Ilmi, Zainal. "Islam Sebagai Landasan Perkembangan Ilmu Pengetahuan Dan Teknologi”. Vol: XV, No. 1, edisi :Juni 2012.

[11]. Iqbal, Muhammad. "Rekonstruksi Pemikiran Islam”. Penerbit: Kalam Mulia. 1994.

[12]. Jamal Fakhri. "Sains Dan Teknologi Dalam Al-Qur'an Dan Implikasinya Dalam Pembelajaran". TA’DIB, Vol. XV No. 01. Edisi, Juni 2010.

[13]. Kurniawan, Rahmad. "Kecerdasan Buatan dan Sunnatullah dalam Terminologi Islam”. February $1,2015$.

[14]. Malik, Dedy Djamaluddin. "Peranan Pers Islam di Era Informasi”. Kumpulan artikel dalam Islam dan Era Informasi, Jakarta: Pustaka Panjimas, 1989.

[15]. Masum, Abdul Kadar Muhammad. "Ethical Issues in Computer use: A Study from Islamic Perspective". Global Journal of Computer Science and Technology Interdisciplinary Volume 13 Issue 2.2013 .

[16]. Masum, Abdul Kadar Muhammad., Ullah, Md. Cholem., Azad, Md. Abul Kalam. "Information Technology (IT) Ethics in the Light of Islam". IIUC STUDIES Vol. 9, December 2011 (p 243260).

[17]. Nassar, A Jamal., Hayajneh, Almsafir, Mahmoud KH. "Relation between Social Network and Da'wah to Islam A case study on Jordanian students Islam”. International Journal on Islamic Applications in Computer Science And Technology, Vol. 1, Issue 1, June 2013, 9-18.

[18]. Ramly, Andi Muawiyah. "Peta Pemikiran Karl Marx [Materialisme Dialektis dan Materialisme Historis]". Yogyakarta: LkiS, 2000.

[19]. Sanders, Donald H. "Computer Today". New York : Mcgraw-Hill. 1983.

[20]. https://id.wikipedia.org/wiki/Pencemaran

[21]. https://kompas.id/label/pelambatan-kasus-covid

[22]. http://Bagi Ilmu Komputer.blogspot.co.id/2011/12/ Hubungan IslamdanTeknologi.html

[23]. http://japarsiddiq33.blogspot.co.id/2016/05/tugas-artikel-dampak-teknologi.html

[24]. https://imam bonjol netkom.com/sistem informasi islam dalam menghadapi duniaglobal.html

[25]. https://video.quipper.com/id/blog/quipper-campus/campus-life/bedanya-kuliah-teknikinformatika-teknik-komputer-dan-sistem-informasi/ 